\title{
Effect of Dietary Addition of Chocolate Waste on the Fertility of Japanese Quails
}

\author{
J. Subhashini ${ }^{1 *}$, L. Radhakrishnan ${ }^{2}$, S. Ezhil Valavan ${ }^{3}$ and J. Ramesh ${ }^{4}$ \\ ${ }^{1}$ Institute of Agriculture, TNAU, Trichy, India \\ ${ }^{2}$ Central Feed Technology Unit, TANUVAS, Kattuppakkam, Chennai, India \\ ${ }^{3}$ Poultry Research Station, TANUVAS, Chennai, India \\ ${ }^{4}$ Department of Animal Nutrition, Madras Veterinary College, TANUVAS, Chennai, India \\ *Corresponding author
}

\section{A B S T R A C T}

\begin{tabular}{|l|}
\hline K e y w o r d s \\
Japanese quails, \\
$\begin{array}{l}\text { Chocolate waste, } \\
\text { fertility, Body } \\
\text { weight, Sexual } \\
\text { maturity }\end{array}$ \\
\hline Article Info \\
\hline $\begin{array}{l}\text { Accepted: } \\
\text { 22 June } 2020 \\
\text { Available Online: } \\
\text { 10 July } 2020\end{array}$ \\
\hline
\end{tabular}

\section{Introduction}

The poultry industry has emerged as the fastest growing segment of the livestock sector both globally as well as in India (Lisa and Shukla, 2015). Quail farming is advantageous over other poultry since they require less space for rearing and require less capital. Birds can be sold at an early age of five weeks and they mature at the age of six to seven weeks to lay eggs. Thus the scope of quail farming is increasing throughout India
(Mishra and Shukla, 2014). According to Bamgbose et al., (2004), maize accounts for about 45 to 55 per cent of poultry feed. Therefore any effort to substitute maize in poultry feed will significantly reduce the cost of production (Edache et al., 2005). Efforts to utilize various unconventional feed resources have been tried by several workers. Chocolate waste can be obtained from chocolate manufacturing industry. Chocolate waste is the waste that is produced during production of chocolates due to spillage or due to 
irregular sizes. Chocolate waste is a good source of energy and contains about 21.1 $\mathrm{MJ} / \mathrm{Kg}$ gross energy, $4.7 \%$ crude protein, $18.6 \%$ crude fat and a slightly higher nitrogen free extract (71.4\%) (Rudolf et al., 1980). Hence, this study was conducted to evaluate the effect of addition of chocolate waste on fertility of Japanese quails.

\section{Materials and Methods}

A total of 500 day old Japanese quail chicks were randomly allotted to four treatments with 125 birds in each treatment. The chicks were reared in cage system and offered feed and water ad-libidum. The experiment lasted from 0 to 5 weeks and 7 to 16 weeks. The chocolate required for the study was collected from a private manufacturing company. Four experimental diets were formulated as follows: $\mathrm{T}_{1}$ (control), $\mathrm{T}_{2}(5 \%), \mathrm{T}_{3}(10 \%)$ and $\mathrm{T}_{4}(15 \%)$ inclusion levels of chocolate waste.
The diets were iso-nitrogenous and iso-caloric and formulated as per the BIS Standards (2007). The experimental diets (Brooder and Grower) were analysed for their crude protein, crude fibre and ether extract, calcium and total phosphorus as per AOAC (2000). The metabolisable energy, lysine and methionine content were calculated based on analysed values. The nutrient density of Japanese quail layer diet is presented in table 1. The parameters measured were body weight and age at sexual maturity in birds. Age at sexual maturity was measured as number of days to reach 5 per cent egg production on flock basis.

\section{Statistical Analysis}

Data collected in the biological trial was analysed using ANOVA as per, SPSS version 20.0 for windows.

Table.1 Nutrient density of Japanese quail diet

\begin{tabular}{|c|c|c|c|c|}
\hline \multirow[t]{2}{*}{ Nutrients } & \multirow{2}{*}{$\begin{array}{c}\text { Control } \\
0 \%\left(\mathrm{~T}_{1}\right)\end{array}$} & \multicolumn{3}{|c|}{ Level of Chocolate waste } \\
\hline & & $5 \%\left(T_{2}\right)$ & $10 \%\left(T_{3}\right)$ & $15 \%\left(\mathrm{~T}_{4}\right)$ \\
\hline \multicolumn{5}{|l|}{ Brooder diet (0-3 weeks) } \\
\hline ME (kcal/kg)* & 3022 & 3022 & 3022 & 3022 \\
\hline Crude protein $(\%)^{*}$ & 24.02 & 24.02 & 24.02 & 24.02 \\
\hline Crude fibre $(\%) * *$ & $3.31 \pm 0.05$ & $3.32 \pm 0.04$ & $3.33 \pm 0.04$ & $3.31 \pm 0.05$ \\
\hline Ether extract (\%) ** & $5.44 \pm 0.06$ & $5.43 \pm 0.09$ & $5.44 \pm 0.08$ & $5.43 \pm 0.08$ \\
\hline Lysine * $(\%)$ & 1.19 & 1.20 & 1.19 & 1.20 \\
\hline Methionine * $(\%)$ & 0.49 & 0.49 & 0.49 & 0.49 \\
\hline Calcium $(\%)^{*}$ & 0.81 & 0.81 & 0.80 & 0.80 \\
\hline Available Phosphorus (\%)* & 0.36 & 0.36 & 0.35 & 0.35 \\
\hline \multicolumn{5}{|l|}{ Grower diet (4-5 weeks) } \\
\hline ME (kcal/kg)* & 2903 & 2903 & 2903 & 2903 \\
\hline Crude protein $(\%)^{*}$ & 20.04 & 20.04 & 20.04 & 20.04 \\
\hline Crude fibre $(\%) * *$ & $4.32 \pm 0.05$ & $4.34 \pm 0.05$ & $4.33 \pm 0.06$ & $4.32 \pm 0.04$ \\
\hline Ether extract $(\%) * *$ & $3.57 \pm 0.07$ & $3.58 \pm 0.05$ & $3.58 \pm 0.04$ & $3.57 \pm 0.05$ \\
\hline Lysine * $(\%)$ & 1.13 & 1.13 & 1.12 & 1.13 \\
\hline Methionine * $(\%)$ & 0.49 & 0.49 & 0.48 & 0.48 \\
\hline Calcium $(\%)^{*}$ & 0.63 & 0.64 & 0.63 & 0.63 \\
\hline Available Phosphorus (\%)* & 0.34 & 0.35 & 0.34 & 0.33 \\
\hline
\end{tabular}

* calculated values **Mean of three observations 
Table.2 Body weight and age at sexual maturity in Japanese quails fed with chocolate waste (Mean \pm S.E)

\begin{tabular}{|l|c|c|c|c|}
\hline \multicolumn{1}{|c|}{ Parameters } & $\mathbf{0 \%}\left(\mathbf{T}_{\mathbf{1}}\right)$ & $\mathbf{5 \%}\left(\mathbf{T}_{\mathbf{2}}\right)$ & $\left.\mathbf{1 0} \% \mathbf{( T}_{\mathbf{3}}\right)$ & $\mathbf{1 5} \% \mathbf{( \mathbf { T } _ { \mathbf { 4 } } )}$ \\
\hline $\begin{array}{l}\text { Body weight at sexual } \\
\text { maturity (g) }\end{array}$ & $213.58 \pm 5.62$ & $216.40 \pm 4.75$ & $217.39 \pm 4.62$ & $217.72 \pm 5.24$ \\
\hline $\begin{array}{l}\text { Age at sexual maturity } \\
\text { (days) }\end{array}$ & $41.80 \pm 0.37$ & $42.20 \pm 0.37$ & $42.00 \pm 0.55$ & $42.60 \pm 0.51$ \\
\hline
\end{tabular}

Each value is a mean of 50 observation ${ }^{\mathrm{NS}}$ Values not significant

\section{Results and Discussion}

The body weight and age at sexual maturity is furnished in table 2 . The body weight at sexual maturity in the four treatment groups were $213.58,216.40,217.39$ and $217.72 \mathrm{~g}$ respectively. The body weight at sexual maturity showed no significant difference $(\mathrm{P}$ $>0.05)$ was observed among the treatment groups. The age at sexual maturity though slightly earlier in control birds by nearly one day, compared to chocolate waste fed quails; it is not statistically significant $(\mathrm{P}>0.05)$.

The body weight at sixth week of age in females though slightly higher by 4 grams in 15 per cent chocolate waste fed group compared to control, it was not statistically significant. The study also reveals that age at sexual maturity delayed by nearly one day in chocolate waste fed quails compared to control birds. The delayed sexual maturity is ideal for optimum egg production, egg size and egg volume (Mandal et al., 2004).

It could be concluded that chocolate waste can be added in Japanese quail diet without affecting the fertility of Japanese quails replacing costly cereal grains.

\section{References}

AOAC, 2000. Official methods of analysis. $16^{\text {th }}$ ed. Association of Official Analytical Chemists, Washington, DC.

Bamgbose, A.M., S.D. Ogungbenro, E.E.
Obasohan, M.B. Aruna, I.T. Oteku, U.F. Igene, C.S.O. Otoikhian and J.A. Imasuen, 2004. Replacement value of maize offal/cashew nut for maize in broiler diets. In Proceedings of the 29th Annual Conference of the Nigeria Society for Animal Production. March. 219-221.

BIS (Bureau of Indian Standards). 2007. Indian Standard Poultry Feeds - Specification. $5^{\text {th }}$ edn. New Delhi.

Edache, J.A., M.U.S.A. Usman, E.S. Haruna, J.O. Esilonu, I. Jibrin, Okpala, E.J. and I.G. Dogo, 2017. Replacement Value of Guinea Corn for Maize in Practical Diet Fed to Quail (Coturnix coturnix japonica) Chicks. Anim. Res. Int., 2(2): 311-313.

Lisa, A and R. Shukla, (2015). An analysis of opportunities and challenges in poultry sector in global and Indian perspectives. Int. J. Manag. Soc. Sci. res., 3(1): 27-35.

Mandal, A.B., A.S. Yadav, T.S. Johri and N.N. Pathak, 2004. Nutrition and disease management of poultry. 1. International Book Distributing Co., Lucknow. 184.

Mishra, P and S. Shukla, 2014. Quail Farming: An Introduction. Int. J. Life Sci. 2(2): 190193.

Rudolf, T.S., A.J. Sheppard, D.R. Newkirk and W.D. Hubbard, 1980. Individual lipids and proximate analysis of various foods. 5. Candy bars. J. Agric. Food Chem., 28: 889-891.

SPSS, Statistical Package for the Social Sciences. Version 20.0 software for Windows. 


\section{How to cite this article:}

Subhashini, J., L. Radhakrishnan, S. Ezhil Valavan and Ramesh, J. 2020. Effect of Dietary Addition of Chocolate Waste on the Fertility of Japanese Quails. Int.J.Curr.Microbiol.App.Sci. 9(07): 3295-3298. doi: https://doi.org/10.20546/ijcmas.2020.907.384 